\title{
Metody rozpraszania światła w ocenie jakości środków smarowych
}

\begin{abstract}
Metody analityczne wykorzystujące zjawisko rozpraszania światła (ang. light scattering, LS) są narzędziem do charakterystyki mikrostruktury układów koloidalnych i oceny ich stabilności w czasie, użytecznymi w ocenie jakości środków smarowych i eksploatacyjnych. Dynamiczne rozpraszanie światła (ang. dynamic light scattering, DLS) w sposób nieinwazyjny umożliwia pomiar wielkości cząstek w dyspersji. Parametry interakcji dynamicznego i statycznego rozpraszania światła (SLS) są pomocne przy szybkim określaniu i porównywaniu stabilności rozcieńczonych koloidów. Obserwacja zmian natężenia światła rozproszonego przez cząstki na różnych wysokościach próbki informuje o charakterze występującej utraty stabilności i umożliwia wcześniejsze wykrycie zmian niż metody klasyczne. W artykule przedstawiono metodyki wykorzystywane w ICSO wraz z przykładami ich zastosowania w praktyce do oceny jakości przemysłowych układów koloidalnych.
\end{abstract}

Słowa kluczowe: rozpraszanie światła, stabilność układu koloidalnego, rozmiar cząstek.

\section{Light scattering methods for the evaluation of the quality of industrial lubricants}

Light scattering (LS) analytical methods are used to characterize the microstructure of colloidal systems and to evaluate their stability over time, useful in assessing the quality of lubricants and operating fluids. DLS (dynamic light scattering) is a non-invasive method for the determination of the size of the particles in dispersion. Interaction parameters for dynamic and static light scattering (SLS) are helpful in the rapid determination and comparison of the stability of diluted colloids. Observation of changes in light intensity scattered by particles at different heights of the sample indicates the nature of the resulting loss of stability and allows earlier detection of changes than classical methods. The paper presents methodologies for three LS methods applied in ICSO and the correlation of their results for practical application. The evaluation of the quality of various industrial lubricants is presented for formulations analyzed and developed in ICSO.

Key words: light scattering, stability of colloids, size of particles.

\section{Wprowadzenie}

Większość stosowanych w przemyśle środków smarowych i eksploatacyjnych to układy koloidalne. Oleje przemysłowe (w tym oleje emulgujące), emulsje, smary czy półprodukty do ich otrzymywania są to substancje jednorodne makroskopowo, których mikrostruktura składa się z cząstek (kropel, rysunek 1) o rozmiarach $1 \div 1000 \mathrm{~nm}[2,10]$ zawieszonych w fazie ciągłej. Struktura wewnętrzna koloidów może się zmieniać w czasie, co jest związane z migracją cząstek lub ze zmianą ich wielkości. Efektem zmian są takie zjawiska jak śmietankowanie, sedymentacja, flokulacja, koalescencja kropel lub inne formy utraty stabilności $[5,10]$. Zmiany w mikrostrukturze koloidu nie pozostają bez wpływu na jego funkcje. Część produktów przemy- słowych poddawana jest długotrwałym normowanym badaniom stabilności [14]. Szybszą i nieinwazyjną identyfikację zmian umożliwia monitorowanie spektroskopowe próbek za pomocą metod analitycznych wykorzystujących zjawisko rozpraszania światła (z ang. light scattering, LS). Sposób, w jaki promieniowanie jest rozpraszane przez cząstki, zależy od ich rozmiaru, ruchliwości, kształtu i w pewnym stopniu od ich natury chemicznej [9].

Dynamiczne rozpraszanie światła (DLS) umożliwia wyznaczenie średnicy hydrodynamicznej oraz dyspersji rozmiarów (PDI) cząstek. Są to istotne parametry charakteryzujące mikrostrukturę koloidu, lecz nieinformujące bezpośrednio na temat zdolności próbki do zachowania tej mikrostruktury 


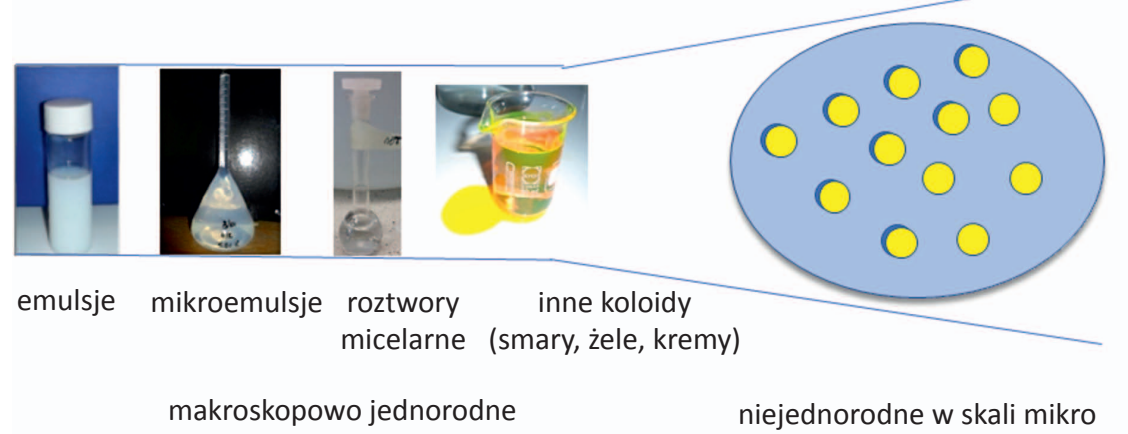

Rys. 1. Koloidy stosowane w przemyśle - przykłady

bezpośredniej oceny zmian zachodzących w próbce $[6,8]$.

Badania dotychczas wykonywane w ICSO obejmowały ocenę stabilności oraz charakterystykę mikrostruktury przemysłowych koloidów stosowanych jako środki smarowe i eksploatacyjne m.in. w górnictwie, hutnictwie, papiernictwie i przemyśle płyt drewnopochodnych. Są to koncentraty cieczy obróbczych i hydraulicznych, półprodukty do ich otrzymywania oraz ciecze robocze z nich wytworzone,

w czasie. Stabilność można ocenić poprzez wyznaczenie parametru związanego z rozpuszczalnością próbki w danym medium, drugiego współczynnika wirialnego $\left(A_{2}\right)$, metodą statycznego rozpraszania światła (SLS) [3, 7].

Natężenie światła wstecznie rozproszonego (RW) oraz transmitancja $(\mathrm{T})$ mierzone w zależności od wysokości warstwy cieczy w naczyniu pomiarowym dostarczają danych do emulsje powłokotwórcze i inne. W artykule scharakteryzowano wybrane metodyki stosowane w ICSO. Omówiono kwestie związane $\mathrm{z}$ analizą rozmiaru cząstek w rozcieńczeniu i w próbkach stężonych. Na przykładzie emulsji impregnującej do opakowań przedstawiono szybką ocenę stabilności koloidu z wykorzystaniem analiz MLS (wielokrotne rozpraszanie światła), DLS i SLS.

\section{Metodyka pomiarów LS stosowana w ICSO}

\section{$D L S$}

Do określenia średniego rozmiaru i rozkładu wielkości cząstek metodą DLS pomiary wykonywano za pomocą aparatu Zetasizer Nano ZS (Malvern), wyposażonego w laser (He-Ne) emitujący spolaryzowaną wiązkę światła o długości fali $633 \mathrm{~nm}$. Pomiary przeprowadzono pod kątem $173^{\circ}$ w określonej temperaturze. Średnicę hydrodynamiczną $\left(D_{H}\right)$ wyznaczono za pomocą równania Stokesa-Einsteina (równanie 1) [9]:

$$
D=\frac{k T}{3 \pi \eta D_{H}}
$$

gdzie:

$D$ - współczynnik dyfuzji translacyjnej,

$k$ - stała Boltzmanna,

$T$ - temperatura,

$\eta$ - lepkość dynamiczna rozpuszczalnika.

Dla próbek wymagających rozcieńczenia przygotowywano roztwory z użyciem wody filtrowanej przez filtry Millipore Express Plus ${ }^{\mathrm{TM}} \mathrm{o}$ średnicy porów $0,22 \mu \mathrm{m}$.

\section{SLS}

Do wyznaczenia drugiego współczynnika wirialnego $\left(A_{2}\right)$ wykorzystano statyczne rozpraszanie światła [3, 7]. Pomiary przeprowadzono za pomocą urządzenia Zetasizer Nano ZS. Początkowo dla trzech wybranych stężeń wykonano pomiary rozkładu wielkości cząstek metodą DLS. W przy- padku otrzymania pojedynczych pików i rozmiaru niezależnego od stężenia, dla wzorca o znanym stosunku Rayleigha $\left(R_{0}\right.$, toluen), rozpuszczalnika oraz próbek w zadanych stężeniach, wykonano pomiary intensywności rozproszonego światła (liczba zliczeń fotonów na sekundę, kcps). Wyniki przedstawiono w postaci wykresu Debye'a, w którym zależność $\frac{K C}{R_{0}}$ jest funkcją stężenia próbki, a $A_{2}$ wyznaczono z nachylenia tej krzywej [7] (równanie 2):

$$
\frac{K C}{R_{0}}=\frac{1}{M_{w}}+2 A_{2} C
$$

gdzie:

$K$ - stała zależna m.in. od współczynnika załamania światła dla próbki,

$C$ - stężenie próbki,

$R_{0}$ - stosunek Rayleigha,

$M_{w}$ - masa molowa mierzonych cząstek.

\section{Pomiar T $\boldsymbol{i}$ RW}

Do pomiarów transmitancji (T) oraz natężenia światła wstecznie rozproszonego (RW) w zależności od wysokości warstwy cieczy w naczyniu pomiarowym wykorzystano aparat Turbiscan Lab Thermo (Formulaction), wyposażony w laser emitujący wiązkę światła o długości fali $880 \mathrm{~nm}$. Detektor transmisji rejestruje sygnał światła przechodzącego przez próbkę (pod kątem $0^{\circ} \mathrm{W}$ stosunku do wiązki lasera), natomiast detektor RW rejestruje sygnał światła 
wstecznie rozproszonego przez próbkę pod kątem $45^{\circ}$ (równania 3 i 4) $[6,13]$ :

$$
\begin{gathered}
R W=\frac{1}{\sqrt{l^{*}}} \\
l^{*}(\varphi, d)=\frac{2 d}{3 \varphi(1-g) Q_{s}}
\end{gathered}
$$

gdzie:

$l^{*}$ - średnia droga fotonu w układzie zdyspergowanym,

$\varphi$ - ułamek objętościowy cząstek,

$d$ - średnia średnica cząstek,

$g$ i $Q_{s}$ są parametrami optycznymi wyznaczonymi na podstawie teorii rozpraszania światła zaproponowanej przez Mie [13]. Zmiany RW w zależności od wysokości warstwy próbki w naczyniu pomiarowym są odzwierciedleniem zmian w mikrostrukturze układu koloidalnego - migracji cząstek fazy zdyspergowanej oraz zmiany ich wielkości.

Do porównania stabilności w czasie poszczególnych próbek wykorzystano indeks stabilności TSI, wyznaczany po- przez ilościowe porównanie wszystkich skanów w próbce (równanie 5):

$$
T S I=\sqrt{\frac{\sum_{i=1}^{n}\left(x_{i}-x_{R W}\right)^{2}}{n-1}}
$$

gdzie: $x_{i}$ jest średnią wartością natężenia światła rozproszonego w danej chwili, $x_{R W}$ jest średnią $x_{i}$, a $n$ to całkowita liczba skanów. Im niższa wartość TSI, tym mniej zmian zachodzi w próbce [8].

Przed pierwszym pomiarem próbki ręcznie wymieszano i pozostawiono do odpowietrzenia. Wykonywano pomiary dla prób w formie skoncentrowanej (bez rozcieńczenia), w określonej temperaturze. Aby określić, czy zaobserwowana utrata jednorodności jest odwracalna, po badaniu wymieszano próbki ręcznie oraz z wykorzystaniem ultradźwięków i ponownie przeprowadzono pomiary T oraz RW. Wyniki porównano z tymi uzyskanymi na początku badania. W przypadku gdy widma się pokrywały, utratę stabilności uznawano za odwracalną.

\section{Przykłady zastosowania metod LS do oceny jakości wybranych środków smarowych i eksploatacyjnych}

\section{Rozmiar kropel fazy zdyspergowanej emulsji powtokotwórczej w zależności od jej stężenia}

Podstawy teoretyczne metody DLS zostały szczegółowo opisane w publikacjach [1,9]. Monochromatyczna, spójna i spolaryzowana wiązka światła laserowego oświetla próbkę, światło jest rozpraszane przez zdyspergowane cząstki i rejestrowane przez detektor, z którego sygnał wyjściowy (zależność intensywności rozproszonego światła od czasu) podawany jest do korelatora. Następuje wyznaczenie współczynnika dyfuzji translacyjnej $(D)$, a za pomocą równania Stokesa-Einsteina (równanie 1) obliczana jest średnica hydrodynamiczna. Średnica hydrodynamiczna $\left(D_{H}\right)$ to średnica, jaką miałaby sferyczna cząstka poruszająca się w sposób zbliżony do badanych cząstek, które niekoniecznie są sferyczne (rysunek 2).

Znajomość $D_{H}$ umożliwia określenie rozmiaru cząstek (kropel) w dyspersji, konieczne do zakwalifikowania produktu do odpowiedniego rodzaju koloidu. Szerokość roz-
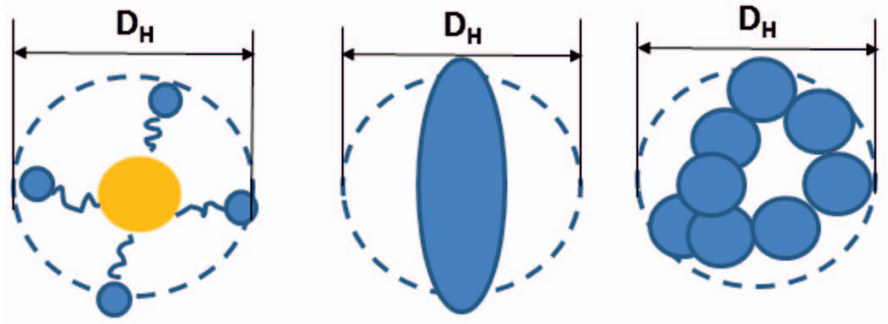

Rys. 2. Schematyczne przedstawienie średnicy hydrodynamicznej dla różnych rodzajów cząstek, od lewej:

kropla substancji hydrofobowej otoczona cząsteczkami emulgatora; cząstka elipsoidalna; cząstki znajdujące się blisko siebie (aglomerat)

kładu wielkości cząstek informuje o zróżnicowaniu ich rozmiarów (dyspersji rozmiarów, PDI), a liczba pików - o liczbie rodzajów obiektów występujących w próbce. W tablicy 1 zestawiono wybrane parametry określające jakość pomiarów DLS.

Tablica 1. Wybrane parametry określające jakość pomiarów DLS

\begin{tabular}{|l|l|c|c|}
\hline \multicolumn{1}{|c|}{ Parametr } & \multicolumn{1}{|c|}{ Opis } & Przyjmowane wartości & Najlepsza wartość \\
\hline In range [\%] & określa jakość danych & $0 \div 100$ & $>90$ \\
\hline Intercept & stosunek sygnału do szumu & $0 \div 1$ & $0,85 \div 0,95$ \\
\hline Średnia liczba zliczeń fotonów [kcps] & natężenie rozproszonego światła & $>0$ & $\begin{array}{c}\text { wyższe o około } 20 \mathrm{kcps} \\
\text { od rozpuszczalnika }\end{array}$ \\
\hline
\end{tabular}


W pomiarach średnicy cząstek nierozcieńczonych koloidów grupa cząstek znajdujących się blisko siebie (aglomerat, rysunek 2) często silnie rozprasza światło, przysłaniając sygnały pochodzące od poszczególnych kropel. Zjawisko to prowadzi do zawyżenia średniej wielkości cząstek. Rozcieńczenie układu odpowiednim rozpuszczalnikiem, tożsamym z fazą ciągłą, jest wskazane w przypadkach, w których rozmiar cząstek nie zależy od stężenia próbki. Istotne jest przeprowadzenie pomiarów w kilku stężeniach i obserwacja parametrów krzywej korelacji.

Rysunek 3A przedstawia wyniki pomiarów dla nierozcieńczonej parafinowo-wodnej emulsji, a rysunek 3B analizę tej próbki w stężeniu $1 \%(v / v)$. Na rysunku 3A widoczne są trzy piki - o $D_{H}=7 \mathrm{~nm}, 20 \div 50 \mathrm{~nm}$ i $350 \mathrm{~nm}$. $D_{H s r}$ wynosi $1377 \mathrm{~nm}$, mimo że piki o takim maksimum nie wystę- pują w rozkładzie. Krzywe korelacji nie są powtarzalne (rysunek 3A). Dyspersja rozmiarów wynosi 1, co wskazuje na duże zróżnicowanie rozmiarów obiektów. W okolicy linii bazowej krzywej korelacji zależność jest niemonotoniczna, co świadczy o obecności obiektów powyżej $1000 \mathrm{~nm}$ [4]. Parametry określające jakość pomiarów (in range i intercept) znajdują się poza wskazanym zakresem, co wskazuje na to, że skoncentrowana emulsja nie nadaje się do analizy DLS.

Na mikrofotografii SEM emulsji nierozcieńczonej (rysunek 3C) widoczne są obiekty o średnicy $88 \div 840 \mathrm{~nm}$. Rozmiar ten zgadza się z rozmiarem cząstek otrzymanym metodą DLS dla emulsji 1\% $(v / v)$. Widoczne na rysunku $3 \mathrm{C}$ krople emulsji znajdują się w bardzo bliskiej odległości względem siebie, jak na rysunku 2, co doprowadziło do zawyżenia $D_{H \dot{s} \text { r. }}$ Piki odpowiadające mniejszym cząstkom na rozkładzie próbki stężonej, których nie ma na rozkładzie próbki rozcieńczonej, są natomiast efektem wielokrotnego rozpraszania światła, zjawiska niepożądanego w przypadku pomiarów DLS [12]. W próbce skoncentrowanej, ze względu na wzajemną bliskość cząstek, dochodzi do wielokrotnego rozpraszania pojedynczego fotonu, przez co sygnał padający na detektor jest słabszy i pojawiają się piki odpowiadające mniejszym cząstkom.

Dla stężenia $1 \%(v / v)$ (rysunek 3B) otrzymano powtarzalny monomodalny rozkład wielkości kropel o zakresie $100 \div 1000 \mathrm{~nm}$, a krzywe korelacji były powtarzalne. $D_{H \dot{s} r}$ wynosiła $350 \mathrm{~nm}$.

Na obecność aglomeratów cząstek emulsji wskazuje wysoka dyspersja rozmiarów, tj. PDI $\approx 1$, brak powtarzalności krzywych korelacji, zależność rozkładu wielkości cząstek od stężenia emulsji, niemonotoniczność krzywej korelacji w okolicy linii bazowej, obecność na rozkładzie wielkości cząstek niepowtarzalnych pików o niskiej intensywności odpowiadających małym rozmia-
Rys. 3. Analiza wielkości kropel dla emulsji parafinowej w $25^{\circ} \mathrm{C}$ : nierozcieńczonej (A), w stężeniu 1\% (v/v) (B) oraz mikrofotografia SEM otrzymana dla nierozcieńczonej emulsji (C) 
rom cząstek oraz wysoka (powyżej $1000 \mathrm{~nm}$ ) wartość średniej średnicy hydrodynamicznej, niewynikająca z rozkładu wielkości cząstek $[4,12]$.

Jeśli chodzi o omawianą emulsję, wskazana jest analiza rozmiaru jej kropel w rozcieńczeniu. Istnieją jednak przypadki, w których rozmiar i morfologia cząstek koloidu silnie zależą od stężenia - cechy takie wykazują między innymi roztwory micelarne surfaktantów.

\section{Rozmiar cząstek mikroemulsyjnych cieczy obróbczych}

Rozmiar cząstek cieczy hydraulicznych i obróbczych jest istotnym parametrem charakteryzującym mikrostrukturę tych cieczy. Rysunek 4 przedstawia zmianę rozkładu wielkości cząstek mikroemulsyjnej cieczy obróbczej w wyniku zastosowania dodatku polimerowej substancji pomocniczej. Mikroemulsja wyjściowa charakteryzowała się monomodalnym rozkładem wielkości cząstek o $D_{H \dot{S} r}=25 \mathrm{~nm}$ (rysunek 4A). Wraz z dodatkiem polimeru (rysunek 4B) pojawił się drugi pik, odpowiadający rozmiarom większych cząstek $(200 \div 1200 \mathrm{~nm})$, a pik o zakresie $D_{H}=10 \div 60 \mathrm{~nm}$ zmniejszył swoją intensywność. Świadczy to o zachowaniu dotychczasowych cząstek mikroemulsji w obecności nowego typu obiektów - kropel emulsji utworzonych z udziałem cząsteczek polimeru lub zagregowanych cząsteczek samego polimeru. Z uwagi na obecność cząstek powyżej $100 \mathrm{~nm}$ ciecz $\mathrm{z}$ dodatkiem polimerowym (rysunek 4B) nie może być już nazywana mikroemulsją [10].

\section{Wplyw homogenizacji ciśnieniowej na stabilność emulsji impregnującej}

Rozkład wielkości czastek nie informuje bezpośrednio o stabilności układu koloidalnego. Stabilność można ocenić poprzez obserwację zmian natężenia światła rozproszonego (RW) przez zdyspergowane cząstki w zależności od wysokości naczynia pomiarowego. Metoda ta jest szczególnie pomocna w określeniu wpływu sposobu otrzymywania danej próbki na jej stabilność. Rysunek 5 przedstawia profil RW dla próbki emulsji impregnującej do papieru sporządzonej bez użycia homogenizacji ciśnieniowej (5A), po jednokrotnej homogenizacji (5B) oraz po homogenizacji dwukrotnej (5C). Lewa strona to dno fiolki, natomiast prawa to górna część naczynia. Linia niebieska oznacza pomiar początkowy, linia czerwona - pomiar po 30 dniach przechowywania.
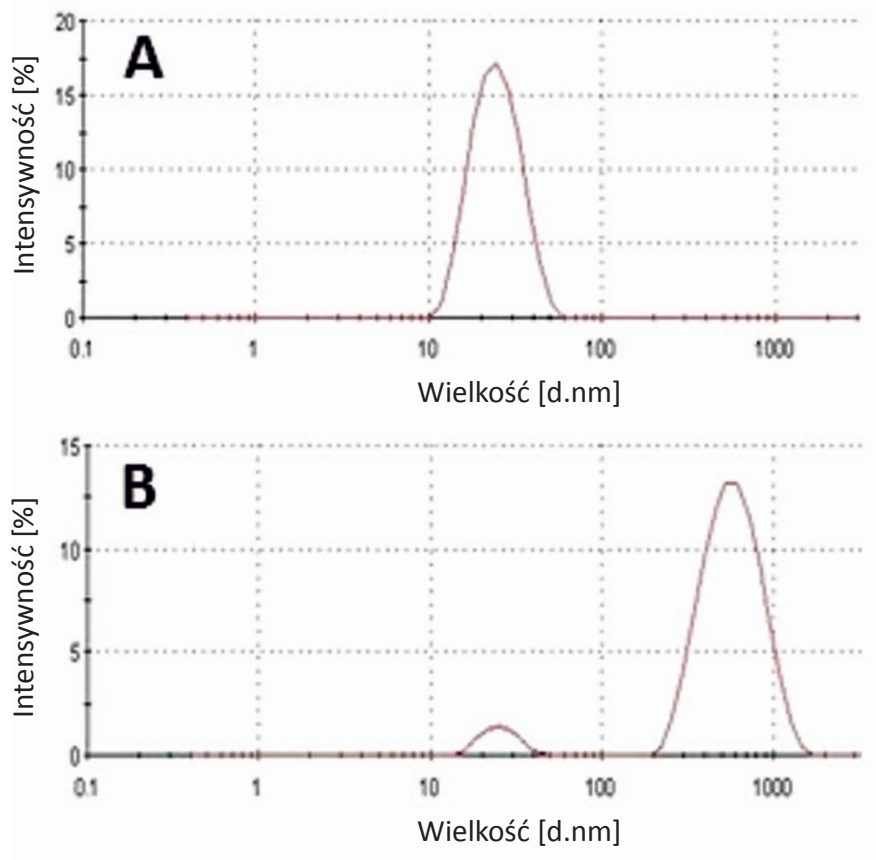

Rys. 4. Rozkład wielkości cząstek mikroemulsyjnej cieczy obróbczej w $25^{\circ} \mathrm{C}$ (A) oraz tej samej cieczy $\mathrm{z}$ dodatkiem polimerowym (B)
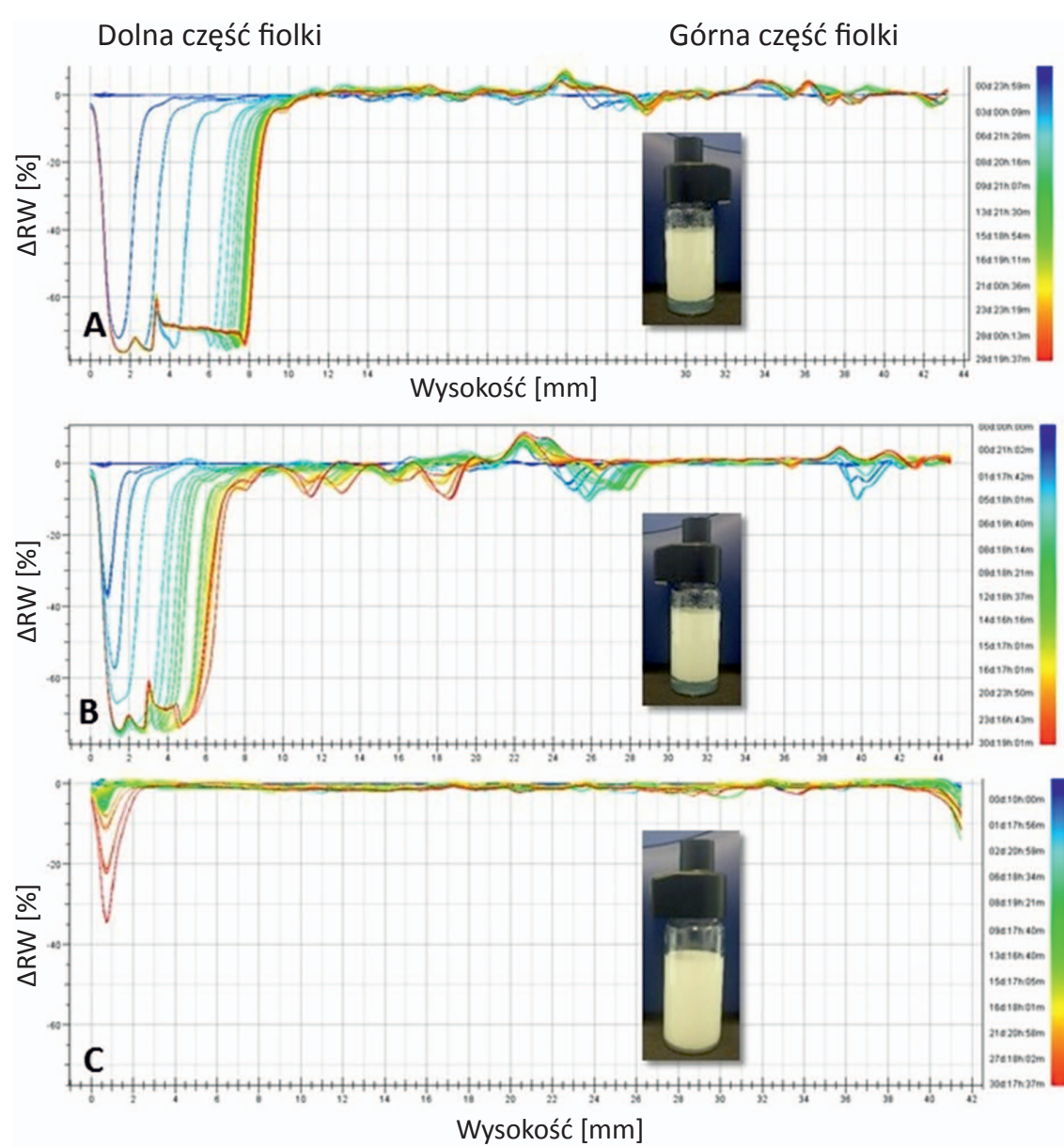

Rys. 5. Profil zmian natężenia światła rozproszonego $(\Delta \mathrm{RW})$ dla emulsji w $30^{\circ} \mathrm{C}$ : niehomogenizowanej (A), homogenizowanej jednokrotnie (B) oraz homogenizowanej dwukrotnie (C). Fotografie przedstawiają emulsje po 30 dniach przechowywania w temperaturze pokojowej 
W przypadku próbki niehomogenizowanej (rysunek 5A) RW już po 3 dniach spadło o około $70 \%$ w dolnej części fiolki. Próbka homogenizowana jednokrotnie (rysunek 5B) charakteryzowała się po tym czasie 38-procentowym spadkiem RW. W żadnej z próbek nie były to zmiany widoczne makroskopowo. W emulsji homogenizowanej dwukrotnie pierwsze zmiany wykryto po 13 dniach (10-proc. spadek RW, zmiany również nie były widoczne makroskopowo).

W próbce niehomogenizowanej po 30 dniach RW spadło o $75 \%$ w około $1 / 5$ objętości naczynia pomiarowego i jest to zmiana widoczna w postaci wydzielonej warstwy wody, podobnie jak na rysunku 5B. W próbce na rysunku 5C RW spadło jedynie o $35 \%$ w niewielkiej objętości. $Z$ rysunku 5 jednoznacznie wynika, że homogenizacja ma znaczący wpływ na stabilność emulsji, co można stwierdzić już wtedy, kiedy zmiany nie są widoczne makroskopowo.

Na rysunku 6 pokazano zmianę współczynnika stabilności TSI w ciągu 3 dni. TSI dla próbki niehomogenizowanej gwałtownie wzrósł już po 20 godzinach w porównaniu do TSI dla emulsji homogenizowanej jednokrotnie i dwukrotnie. Już po 3 dniach można jednoznacznie określić, że dwukrotna homogenizacja jest niezbędna do otrzymania stabilnej emulsji.

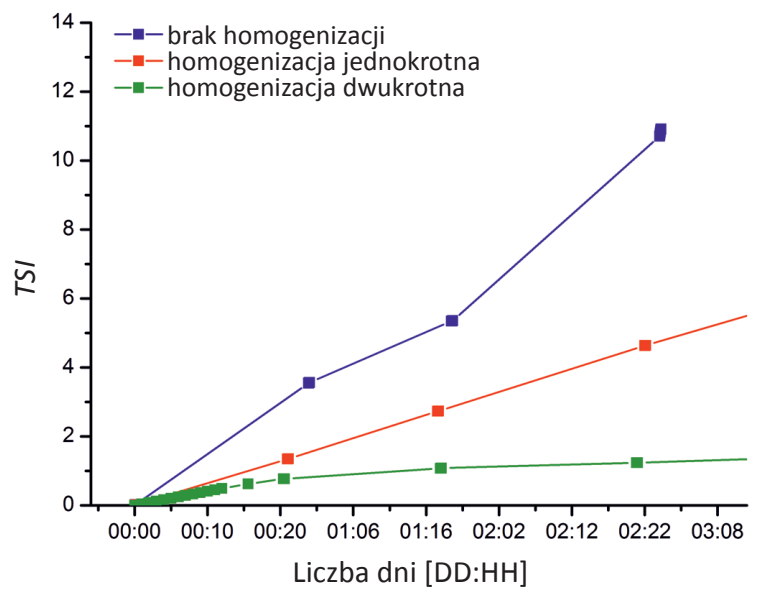

Rys. 6. Zmiany TSI w $30^{\circ} \mathrm{C}$ dla emulsji niehomogenizowanej (niebieska linia), homogenizowanej jednokrotnie (czerwona linia) i homogenizowanej dwukrotnie (zielona linia)

\section{Identyfikacja utraty stabilności i jej odwracalność}

Kiedy niestabilna emulsja po wymieszaniu odzyskuje swoją pierwotną formę, utratę stabilności uznaje się za odwracalną (możliwe jest ponowne zdyspergowanie cząstek w fazie ciągłej). Dla użytkownika może to być akceptowalne - pod warunkiem zachowania właściwości produktu. Rysunek 7A przedstawia profil zmian RW makroskopowo jednorodnej
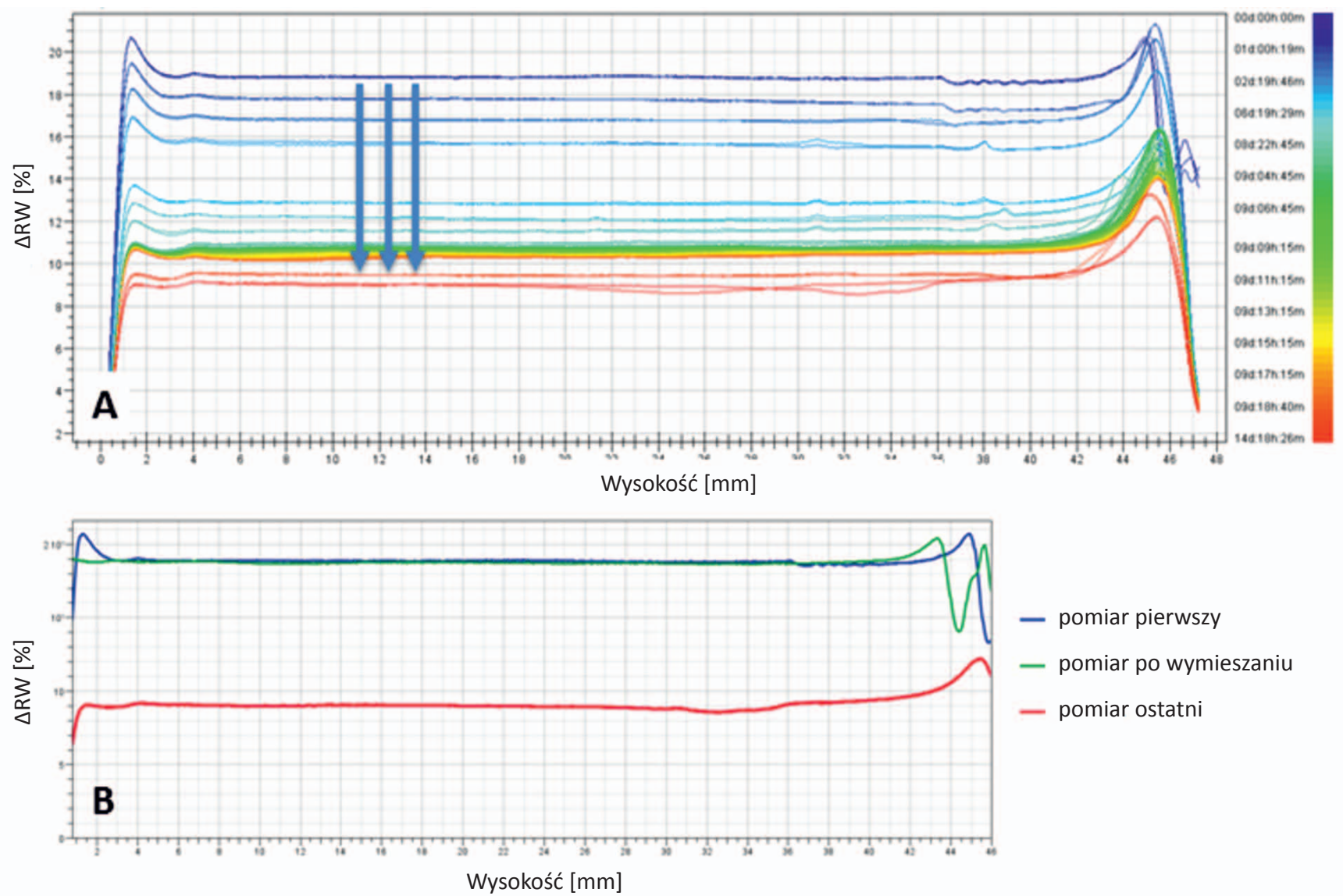

Rys. 7. RW w funkcji wysokości naczynia pomiarowego dla makroskopowo jednorodnej emulsji w 14-dniowym cyklu badań w $30^{\circ} \mathrm{C}(\mathrm{A})$, RW na początku i na końcu badań (linia niebieska i czerwona) oraz po wymieszaniu (linia zielona) (B) 
emulsji po 14-dniowym cyklu pomiarów. Spadek RW w całej objętości emulsji jest związany ze zwiększeniem rozmiaru cząstek. Otrzymany najpóźniej profil RW (rysunek 7B, linia czerwona) znajduje się znacznie poniżej profilu początkowego (rysunek 7B, linia zielona). Profil RW po wymieszaniu (linia niebieska) niemal pokrywa się z pierwszym pomiarem, wskazując na powrót próbki po wymieszaniu do stanu początkowego.

\section{Szybka analiza stabilności za pomoca korelacji wyników DLS, SLS i MLS}

Narzędziem do porównywania stabilności koloidów o zmiennym składzie są parametry korelacji DLS i SLS [3].
Drugi współczynnik wirialny $\left(A_{2}\right)$, wyznaczany z wykresu Debye'a, silnie powiązany z rozpuszczalnością próbki w fazie ciągłej, jest uzupełnieniem danych otrzymanych z DLS. Gdy $A_{2}$ przyjmuje wartości ujemne, próbka ma skłonność do aglomeracji cząstek i utraty stabilności. W przypadku wartości dodatnich próbkę uznaje się za stabilną [3].

Otrzymana w ICSO makroskopowo jednorodna emulsja parafinowo-wodna została poddana kompleksowej ocenie stabilności w czasie 2 dni. Na rysunku 8 przedstawiono profil zmian RW oraz zmianę współczynnika stabilności TSI dla skoncentrowanej emulsji.

Spadek RW u dołu fiolki wynosił 4\% w niewielkiej objętości. U góry widoczny jest nieznaczny jego wzrost. Zmiany
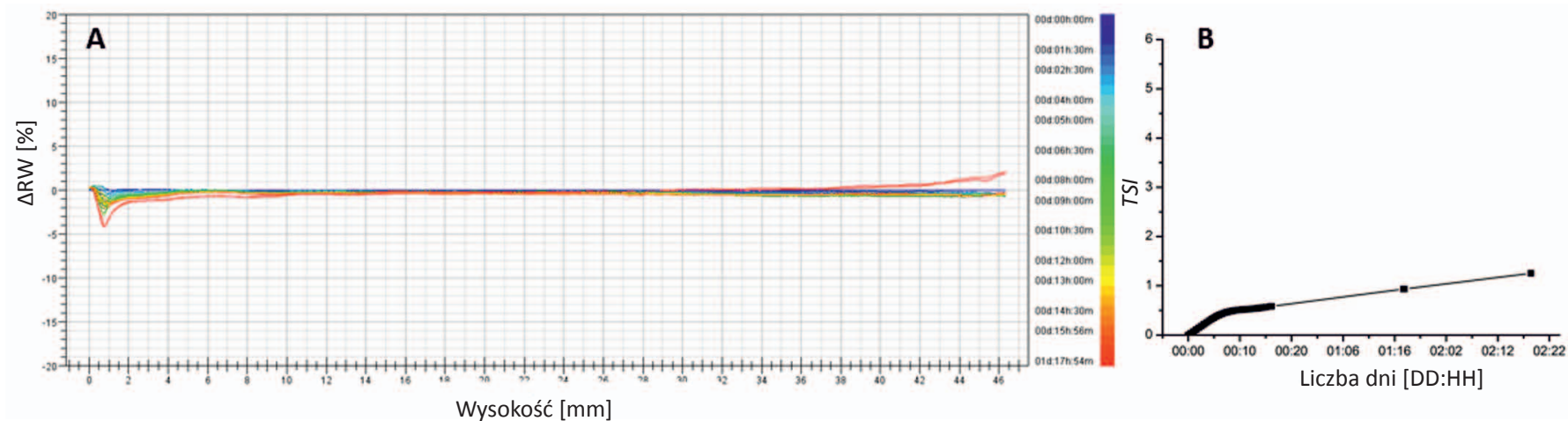

Rys. 8. Profil zmian RW dla skoncentrowanej próbki emulsji parafinowo-wodnej oraz zmiana TSI w czasie 2 dni
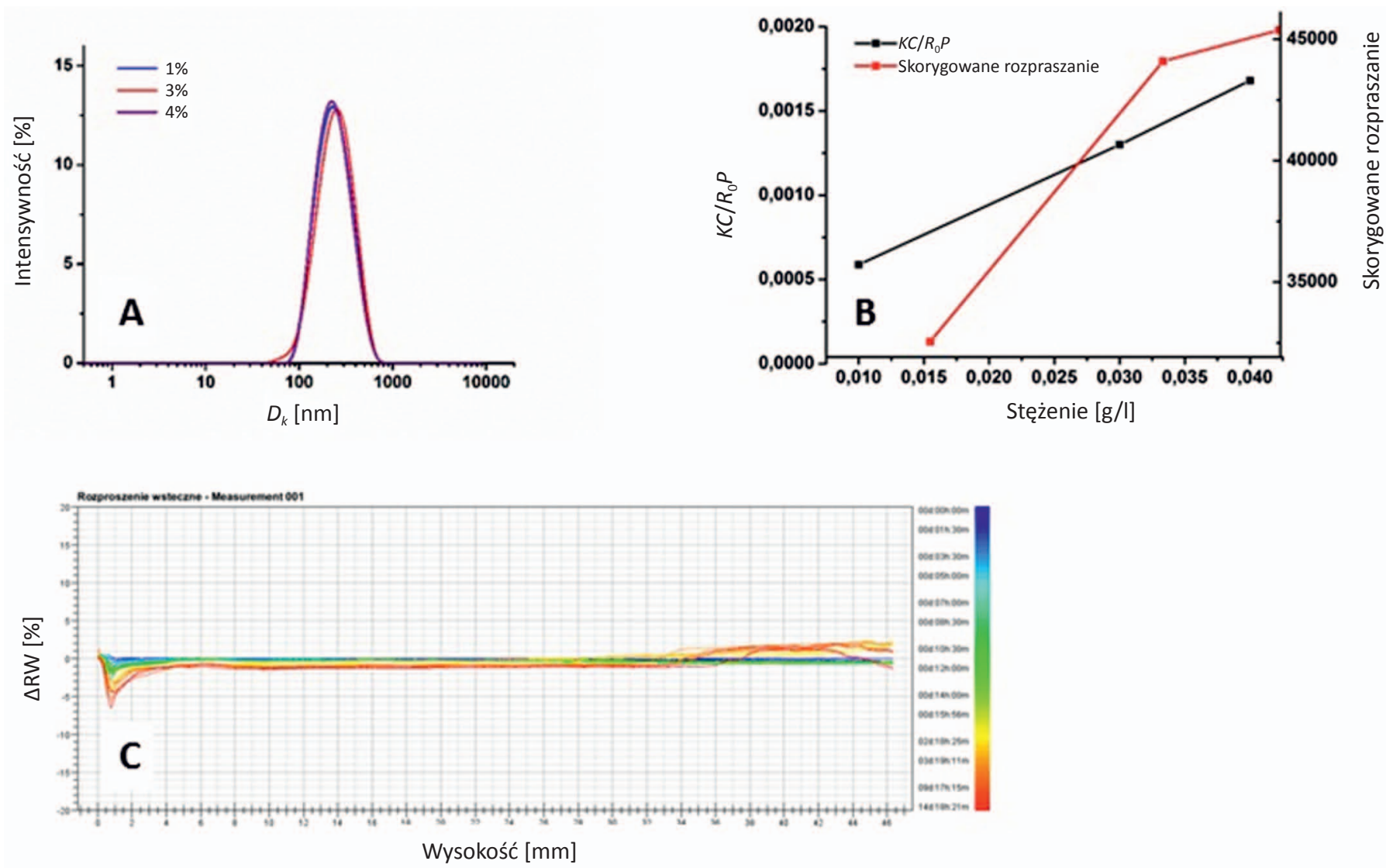

Rys. 9. Rozkłady wielkości cząstek emulsji parafinowo-wodnej w zależności od stężenia (A), wyniki pomiarów SLS (B) oraz 14-dniowy profil zmian RW dla tej emulsji (C) 
sugerują niewielką migrację cząstek do górnych części naczynia. TSI z wartości 0,8 (24 godziny) wzrosło do 1,1 (rysunek 8B, 48 godzin). Rozkład wielkości cząstek był monomodalny i niezależny od stężenia w badanym zakresie (rysunek 9A). Z nachylenia zależności intensywności rozpraszania światła (wyznaczonego metodą SLS) od stężenia wyznaczono $A_{2}$ (rysunek 9B). W tablicy 2 zestawiono istotne parametry badanej emulsji (emulsja 1). Dla porównania pokazano również parametry wybranej emulsji makroskopowo niestabilnej (emulsja 2).

Emulsja 1 charakteryzowała się mniejszą niż emulsja 2 i niezależną od stężenia wielkością kropel. Kcps w trakcie pomiarów DLS dla emulsji 1 nie zmieniało się znacząco, a w pomiarach SLS tworzyło niemal liniową zależność, z której wyznaczono dodatnie $A_{2}$. Dla emulsji 2 wyznacze- nie $A_{2}$ nie było możliwe z uwagi na brak liniowej zależności natężenia rozproszonego światła od stężenia. Dla emulsji 2 po dwóch dniach zaobserwowano wysoki spadek RW, co świadczy o rozpoczynającym się wydzielaniu warstwy wodnej u dołu fiolki. TSI po dwóch dniach dla tej próbki wynosiło 6,6 .

Rysunek 9C przedstawia profil zmian RW emulsji $1 \mathrm{w}$ czasie 14 dni. TSI wzrosło do 2, a RW spadło o 6,5\% u dołu fiolki. Zmiany te były niewidoczne makroskopowo. Próbkę uznano za stabilną. W przypadku emulsji 2 po 14 dniach widoczna była wyraźna warstwa wydzielonej wody u dołu fiolki. Na utratę stabilności tej próbki wskazywała zależność rozkładu wielkości cząstek od stężenia, zmienne kcps, brak możliwości wyznaczenia $A_{2}$, stosunkowo wysokie TSI po 48 godzinach i znaczny spadek RW u dołu fiolki.

Tablica 2. Parametry MLS, DLS i SLS dla emulsji stabilnej i niestabilnej

\begin{tabular}{|l|c|c|}
\hline \multicolumn{1}{|c|}{ Parametr } & Emulsja 1 & Emulsja 2 \\
\hline$D_{H}[\mathrm{~nm}]$ & $\begin{array}{c}250 \mathrm{~nm} \text {, powtarzalna, niezależna od stężenia } \\
\text { w zakresie } 1 \div 10 \%(v / v)\end{array}$ & $\begin{array}{c}350 \mathrm{~nm} \text {, powtarzalna, zależna od stężenia } \\
\text { w zakresie } 1 \div 10 \%(v / v)\end{array}$ \\
\hline Średnie kcps (DLS) & niezmienne w czasie & zmienne w czasie \\
\hline$A_{2}$ & $(+)$ & niemożliwe do wyznaczenia, brak zależności liniowej \\
\hline $\mathrm{TSI}_{24 \mathrm{~h}, 48 \mathrm{~h}, 14 \mathrm{dni}}$ & 0,$8 ; 1,1 ; 2,0$ & 3,$6 ; 6,6 ; 28,5$ \\
\hline Ocena wizualna $(2 \mathrm{dni})$ & jednorodna & jednorodna \\
\hline Maks. $\Delta \mathrm{RW}(2 \mathrm{dni})[\%]$ & $-4,0$ & $-70,0$ \\
\hline Ocena stabilności $(2 \mathrm{dni})$ & stabilna & niestabilna \\
\hline Ocena wizualna $(14 \mathrm{dni})$ & stabilna & wydzielenie warstwy wodnej \\
\hline
\end{tabular}

\section{Podsumowanie i wnioski}

Metody badawcze wykorzystujące zjawisko rozpraszania światła pozwalają na szybszą identyfikację destabilizacji układów koloidalnych niż normowane metody konwencjonalne. MLS, DLS i SLS dostarczają wzajemnie uzupełniających się danych do charakterystyki środków smarowych i eksploatacyjnych stosowanych w przemyśle. Przy interpretacji wyni- ków istotne jest indywidualne podejście do próbki. Najwięcej trudności występuje przy analizie DLS skoncentrowanych koloidów. W przypadku oceny stabilności nowego produktu producent powinien dysponować wiedzą, w jakim stopniu jej utrata będzie dla użytkownika akceptowalna i czy mimo niewielkiej destabilizacji produkt zachowa swoje właściwości.

Prosimy cytować jako: Nafta-Gaz 2017, nr 10, s. 784-792, DOI: 10.18668/NG.2017.10.08

Artykuł nadesłano do Redakcji 16.05.2017 r. Zatwierdzono do druku 29.06.2017 r.

Autorzy składają podziękowania dla Instytutu Technologii Eksploatacji - PIB za przeprowadzenie badań SEM. W pracy wykorzystano wyniki badań otrzymane podczas realizacji projektu współfinansowanego przez Narodowe Centrum Badań i Rozwoju w ramach programu Środowisko naturalne, rolnictwo i leśnictwo, BIOSTRATEG II (ID 298537/16).

\section{Literatura}

[1] Hulst H.C., van de: Light Scattering By Small Particles. Dover Publications, Inc., New York 1981.

[2] IUPAC: Compendium of Chemical Terminology, 2 ed. (the Gold Book). Skompilowane przez: McNaught A.D., Wilkinson A.; Blackwell Scientific Publications, Oxford 1997. Wer- sja online: http://goldbook.iupac.org (2006-) utworzona przez: Nic M., Jirat J., Kosata B.; aktualizacje: Jenkins A. ISBN 0-9678550-9-8.

[3] Kaszuba M.: DLS and SLS Interaction Parameters. Materiały szkoleniowe firmy Malvern, Warszawa 26.03.2016. 
[4] Kaszuba M.: How to Obtain Better Data From Zetasizer Measurements. Materiały szkoleniowe firmy Malvern, Warszawa 26.03.2016.

[5] Kostansek E.: Emulsions. [W:] Kirk-Othmer (ed.): KirkOthmer Encyclopedia of Chemical Technology, John Wiley and Sons 2003, s. 113-133.

[6] Mengual O., Meunier G., Cayre I., Puech K., Snabre P.: TURBISCAN MA 2000: multiple light scattering measurement for concentrated emulsion and suspension instability analysis. Talanta 1999, vol. 50, nr 2, s. 445-456.

[7] Pal R.: Rheology of emulsions containing polymeric liquids. [W:] Becher P. (ed.), Encyclopedia of Emulsion Technology, vol. 4. Marcel Dekker, Inc, Nowy Jork 2004, rozdz. 3 , s. 93-264.

[8] Peng K., Wang X., Lu L., Liu J., Guan X., Huang X.: Insights into the Evolution of an Emulsion with Demulsifying Bacteria Based on Turbiscan. Ind. Eng. Chem. Res. 2016, vol. 55, s. 7021-7029.

[9] Schärtl W.: Light Scattering from Polymer Solutions and Nanoparticle Dispersions. Springer-Verlag, Berlin 2007.

[10] Slomkowski S., Alemán J.V., Gilbert R.G., Hess M., Horie K., Jones R.G., Kubisa P., Meisel I., Mormann W., Penczek S., Stepto R.F.T.: Terminology of polymers and polymerization processes in dispersed systems (IUPAC Recommendations 2011). Pure App. Chem. 2011, vol. 83, nr 12, s. 2229-2259.

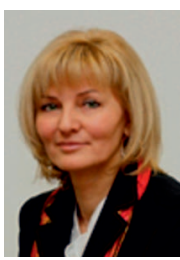

Dr hab. inż. Jolanta IŁOWSKA

Profesor nadzwyczajny ICSO; kierownik Zakładu

Środków Specjalistycznych

Instytut Ciężkiej Syntezy Organicznej „Blachownia”

ul. Energetyków 9

47-225 Kędzierzyn Koźle

E-mail:ilowska.j@icso.com.pl

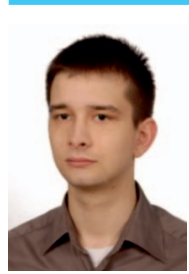

Kamil KORASIAK

Instytut Ciężkiej Syntezy Organicznej „Blachownia”

ul. Energetyków 9

47-225 Kędzierzyn Koźle

E-mail: korasiak.k@icso.com.pl
[11] Stein R.S., Hadziioannou R.: Generalization of the Zimm equation for scattering from concentrated solutions. Macromolecules 1984, vol. 17, nr 5, s. 1059-1062.

[12] Whitby K.T.: Size Measurement of Particles. [W:] Kirk-Othmer Encyclopedia of Chemical Technology. Ed. 5, vol. 12, John Wiley \& Sons Inc. 2015, s. 472-497.

[13] Wriedt T.: Mie Theory: A Review [W:] Hergert W., Wriedt T. (eds.): The Mie Theory. Basics and Applications, Springer Series in Optical Sciences 169, Springer-Verlag Berlin Heidelberg 2012, s. 53-71.

\section{Akty prawne i normatywne}

[14] PN-EN ISO 20783-1:2011E Przetwory naftowe i produkty podobne-Oznaczanie stabilności emulsji cieczy trudnopalnych-Czesść 1: Ciecze kategorii HFAE.

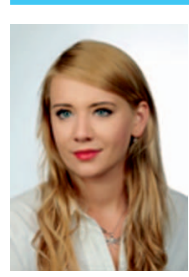

Mgr inż. Julia WOCH

Specjalista badawczo-techniczny

Instytut Ciężkiej Syntezy Organicznej „Blachownia” ul. Energetyków 9

47-225 Kędzierzyn-Koźle

E-mail:woch.j@icso.com.pl

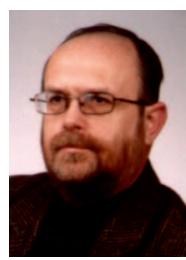

Mgr Bronisław DEJNEGA

Główny Specjalista Badawczo-Techniczny

Instytut Ciężkiej Syntezy Organicznej „Blachownia” ul. Energetyków 9

47-225 Kędzierzyn Koźle

E-mail: dejnega.b@icso.com.pl

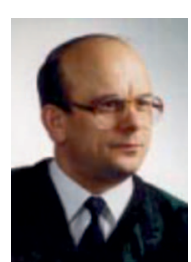

Mgr Jan GNIADY

Główny Specjalista badawczo-Techniczny

Instytut Ciężkiej Syntezy Organicznej „Blachownia”

ul. Energetyków 9

47-225 Kędzierzyn Koźle

E-mail: gniady.j@icso.com.pl 